\title{
Seleksi Pemimpin Nasional Melalui Proses Demokrasi*
}

\section{(Selection of National Leaders Through Democratic Process)}

\author{
M. Makhfudz ${ }^{1}$ \\ Fakultas Hukum Universitas Tama Jagakarsa Jakarta \\ DOI: $10.15408 /$ sjsbs.v5i1.7901
}

\begin{abstract}
:
The condition of the country is currently experiencing a crisis of national leadership both in the hands of state administrators, government organizations and so on. Such conditions when viewed from the history of state administration in the era of the old order and the new order is no better than reform in terms of leaders who have noble ethical morals. This greatly influences the development of the country to advance in competition with other nations. So that the government continues to be preoccupied with revamping activities and regulating the implementation of the state so that it is clean from corruption and extortion which causes high costs. Then immediately take firm action after the Presidential Regulation number 87 of 2016 concerning the Establishment of the Clearing Task Force for Illegal Charges.

Keywords: ethical morality, strategies to face obstacles.
\end{abstract}

\begin{abstract}
Abstrak:
Kondisi Negeri kini sedang mengalami krisis kepemimpinan nasional baik melanda penyelenggara negara, organisasi pemerintahan dan lain sebagainya. Kondisi demikian jika dilihat dari sejarah penyelenggaraan negara di era orde lama dan orde baru tidak lebih baik ketimbang reformasi dari segi pemimpin yang memiliki moral etik yang luhur. Hal ini sangat mempengaruhi berkembangnya negara untuk maju menyaingi negara bangsa lainnya. Sehingga pemerintah terus disibukan oleh kegiatan pembenahan dan pengaturan strategi penyelenggaraan negara agar bersih dari korup dan pungli yang sebabkan biaya tinggi. Kemudian segera melakukan tindakan tegas pasca ditetapkan Perpres nomor 87 tahun 2016 tentang Pembentukan Satuan Tugas Sapu Bersih Pungli.
\end{abstract}

Kata kunci: moral etik, strategi hadapi hambatan.

\footnotetext{
*Diterima: 19 Maret 2018, Revisi: 14 April 2018, Diterima 26 Mei 2018.

${ }^{1}$ M. Makhfud adalah dosen Fakultas Hukum Universitas Tama Jagakarsa Jakarta. E-mail: m-makhfudz@yahoo.com.
} 


\section{Pendahuluan}

Kepemimpinan Nasional di tengah percaturan internasional, pada saat ini sangat penting kita cermati bersama di tengah-tengah suasana persaingan global yang makin meruncing. Pemilihan pemimpin Nasional yang memiliki kepemimpinan nasional yang tepat terasa sangat penting, agar Indonesia bisa menempati posisi terhormat di dunia Internasional. Perubahan sosial politik dan budaya ini menghasilkan pergeseran tatanan yang sebelumnya dianggap mapan, karena telah mengalami proses reformasi. Proses tersebut diikuti dengan bergulirnya proses demokrasi yang ditandai dengan otonomi daerah semakin kuat, pembagian kekuasaan yang lebih merata.

Perubahan bidang ekonomi global memicu perkembangan/perubahan organisasi makin dinamis, di Indonesia mempengaruhi sikap para pemimpinya untuk hidupkan ketergantungan Internasional (Asing) sulit dihindari. Aspek sosial budaya, masuknya pengaruh nilai-nilai barat lewat perkembangan teknologi informasi yang cepat menimpa generasi muda. Perubahan teknologi melahirkan dua efek ke negeri kita yaitu pertama positif melahirkan tokoh-tokoh muda yang inovatif dan visioner, sedang sisi lain efek negatif berupa beberapa perilaku kurang terpuji karena melahirkan perilaku meniru dengan menyerap hal-hal yang mudah diserapnya yang belum tentu mengarah pada hal yang produktif, seperti suka bermalas-malasan, narkoba dan kenakalan remaja. Demikian pula di kalangan pejabat hampir sama seperti narkoba, hilang rasa malunya untuk melakukan sesuatu yang tidak baik seperti korupsi, kolusi (jualbeli jabatan yang kini marak dimana-mana).

Sebagai negara bangsa, masyarakat Indonesia mulai kehilangan perilaku utamanya, antara lain; kini tak lagi menjadi bangsa yang disiplin berlandaskan pada kehormatan, perilaku yang santun. Beberapa pakar menyatakan bahwa demokrasi bergerak liar dalam arti bergerak tanpa kendali, alias "kebablasan," sehingga siapapun cenderung memperjuangkan haknya saja melupakan kewajiban, seperti bila melihat sikap anggota DPR yang merasa tersinggung oleh sikap tegasnya KPK yang terus bongkar korupsi dan kerap mengkapai kader partainya dengan kewenangan KPK yang disebut "Operasi TangkapTangan" (OTT). Terlebih lebih setelah KPK keluarkan daftar Anggota DPR yang terlibat dan dapat aliran dana anggaran e-ktp, kemudian para anggota DPR segera membentuk Pansus Hak Angket KPK, guna mengadili KPK dengan menggunakan Gedung DPR sebagai meja Hijau guna mengadili KPK. Caranya dengan mengundang pada Narapidana kasus Korupsi guna mengungkap kesalahan KPK yang dianggap telah melanggar Hak Asasi Manusia dan Hukum Acara Pidana umumnya. Disamping itu anggota DPR telah gunakan kekuasaan guna desak Presiden untuk segera "Bekukan KPK" dengan cara mencabut kewenangan KPK untuk melakukan "penyadapan" dan desak presiden cabut kewenangan KPK gunakan kewenangan melakukan "Operasi Tangkap Tangan" (OTT). Seolah DPR merasa resah atas sikap tegasnya KPK melakukan 
penyadapan guna mendasarkan melakukan OTT terhadap siapapun yang sedang berjanji akan melakukan suap atau korupsi yang dilakukan oleh siapapun mulai dari anggota DPR sampai Bupati/Walikota ataupun Gubernur. Lebih marah lagi setelah KPK berani memberikan status tersangka pada diri ketua DPR. Dari peristiwa itu membuat DPR makin meradang dengan puncaknya melakukan penuntutan segera Presiden bekukan KPK dan hentikan KPK melakukan Tangkap Tangan. Kemudian DPR dan kelompoknya gunakan kekuasaannya membekingi Lembaga Peradilan guna memenangkan gugatan Pra peradilan, dan terbukti sukses mempengaruhi Hakim untuk memenangkan gugatan Ketua DPR. Ambisi kekuasaan ini tak sampai ini saja, kemudian menggalang kekuatan dengan Lembaga Negara yang dianggap mudah dipengaruhi seperti KEJAGUNG dan POLRI untuk ikut mengadili KPK sebagai pesakitan. Semua mereka ungkap seolah kesalahan ada pada KPK. Mereka sudah tidak ingat lagi komitmen sewaktu pembentukan KPK dengan kewenangan istimewa pada KPK sebagaimana lembaga sejenis KPK di dunia, seperti penulis ketahui di Singapura dan Korea. Seolah Negara ini yang punya hak mengusai hanya DPR dari kondisi ini, kita ingat pada kata-kata atau pesan pemimpin Singapura "Lee Kuan Yew" tentang demokrasi, yaitu: "I believe what a country neend to develop is discipline more than democracy. The Exuberance conduct, which are inimical to development." 2

Dengan tanpa mengurangi arti dari usaha para pemimpin Indonesia masa lalu maupun masa kini terasa sekali bahwa saat ini perilaku bangsa ini yang biasanya dikenal penuh kesantunan ternyata telah berubah. Disamping itu juga diisyaratkan dari sebuah ajaran agama yang bersumber pada hadis Nabi Muhammad Saw, yang diriwayatkan oleh Imam Bukhari yang berbunyi: "Akan datang kepada manusia suatu zaman, dimana orang tidak peduli lagi tentang harta yang didapatnya apakah dari yang halal atau dari yang haram. ${ }^{3}$

Kejadian tersebut diatas tidak perlu menjadi penghambat untuk menuju kearah perbaikan, mengingat bagaimanapun harus diakui, bahwa dalam gerak masa yang terus berjalan kita sebagai bangsa telah mencapai berbagai keberhasilan dalam mengatasi kesulitannya, seperti telah merubah sistem demokrasi makin terbuka, diakuinya kebebasan berpendapat, kebebasan pers, lebih terlindunginya hak asasi manusia dan sebagainya.

\section{Permasalahan}

Permasalahan bangsa yang kini dihadapi bersama, setelah terjadi perubahan besar disatu sisi telah melahirkan hal yang positif, seperti terjadinya

\footnotetext{
${ }^{2}$ Harian Kompas terbitan tanggal 21 desember 2007 tulisan Amich Alhumnire, tentang exuberance" dari Demokrasi"

${ }^{3}$ M. Quraish Shihab, Wawasan Alquran, (Bandung: Penerbit Mizan 1996), h.254.
} 
kebebasan berpendapat, berorganisasi serta pers yang dianggap mampu mengatasi berbagai masalah yang dihadapi oleh suasana krisis global tapi disisi lain terjadinya kelompok di kalangan masyarakat, muncul kelompok apatisme yang dicerminkan adanya kelompok warga yang tidak mau aktifgunakan hak pilihnya, mereka disebut golput telah meningkat dari dekade ke dekade. Namun oleh pemimpin Singapura Lee Kuan Yew di Indonesia telah terjadi "exu berance" (demokrasi kebablasan), karena reformasi lebih melahirkan perilaku yang jauh dari disiplin dan kehormatan. Ini semua ditandai kejadian memalukan pada kalangan pemimpin, terjadi pada pemimpin daerah yaitu pada para Bupati/Walikota yang tertangkap tangan KPK berjumlah 79, belum terhitung yang ada di lingkungan DPR setelah terbongkarnya Mega Korupsi E-KTP.

Jadi permasalahan bangsa ini dapat disimpulkan, bahwa negeri ini sedang terjadi krisis kepemimpinan, sehingga tepatlah judul dalam makalah ini "Seleksi Pemimpin Nasional Melalui Proses Demokrasi" sehingga dengannya dicari kepemimpinan yang tepat untuk pemimpin bangsa ini kedepan" Hal ini perlu dijadikan topik, karena peringkat negeri terkorup terus meningkat. Hasil survey World Economic forum Indonesia di tahun 2015 jadi peringkat ke 88 dengan skor CPI 36. Jadi Indonesia tingkat korupsinya meningkat 2 poin dari tahun 2014 berada di peringkat 107.4

\section{Demokrasi Ala Kaum Yang Mengaku Reformis}

Gambaran diatas adalah merupakan kejadian yang tidak perlu menjadi penghambat untuk menuju ke arah perbaikan. Mengingat bagaimanapun harus diakui bahwa dalam gerak tahun berjalan kita pun telah mencapai beberapa keberhasilan dalam mengatasi kesulitan bersama. Keberhasilan ini merupakan modal dasar negara bangsa untuk secara optimis terus menuju kesejahteraan dan menyelesaikan banyak pekerjaan rumah. Salah satu pekerjaan rumah yang harus dicermati adalah menaikkan daya saing bangsa, serta menciptakan iklim investasi yang kondusif.

Di alam globalisasi, negara yang bisa bertahan hidup hanya negara yang memiliki daya saing kuat, sehingga mampu bertahan dengan kemandiriannya. Bagaimana daya saing Indonesia? penulis menyetir tulisan yang pernah penulis tulis dalam buku Hukum Adminstrasi Negara terbitan Graha Ilmu 2013, yang didasarkan pada hasil survey Word Economic Forum (WEF). Index daya saing global Indonesia tahun 2012 turun. Tahun 2011 berada pada posisi 46 tahun 2012 turun keposisi 50 dari 144 negara, namun di tahun 2015 kita bersyukur bisa naik menjadi 43 (Lihat Grafik dibawah ini). ${ }^{5}$

\footnotetext{
${ }^{4}$ Laporan KPK 2015

${ }^{5}$ Makhfudz, Hukum Adminstrasi Negara, (Jakarta: Graha Ilmu, tth), h.64, Lihat juga: Sumber CPI dari Word Economic Forum 2015 dn Berlsmenn Fondation Index.
} 
Tabel Proses Ijin, dibandingkan 5 negara

\begin{tabular}{|l|l|l|l|}
\hline & \multicolumn{3}{|c|}{ Periode } \\
\hline & & $2012-2013$ & $2014-2015$ \\
\hline 1 & Singapura & 2 hari & 2 hari \\
\hline 2 & Malaysia & 10 hari & 7 hari \\
\hline 3 & Thailand & 12 hari & 10 hari \\
\hline 4 & Brunai & 14 hari & 14 hari \\
\hline 5 & Indonesia & 33 hari & 21 hari \\
\hline
\end{tabular}

Indonesia masih sangat ketinggalan dibandingkan dengan beberapa negara setara, seperti Thailand, Singapura, Malaysia, Meksiko bahkan Vietnam seperti tertera dalam bagan ini. ${ }^{6}$

\begin{tabular}{|l|l|l|l|l|l|}
\hline & & \multicolumn{5}{|c|}{ Peringkat } \\
\hline & Negara & $2010-2011$ & $2011-2012$ & $2012-2013$ & 2015 \\
\hline 1 & Singapura & 3 & 2 & 2 & 1 \\
\hline 2 & Malaysia & 26 & 21 & 25 & 23 \\
\hline 3 & Brunai & 28 & 28 & 28 & 28 \\
\hline 4 & Thailand & 38 & 39 & 38 & 38 \\
\hline 5 & Indonesia & 44 & 46 & 50 & 43 \\
\hline 6 & Philipina & 85 & 75 & 65 & 65 \\
\hline 7 & Vietnam & 59 & 65 & 75 & 75 \\
\hline 8 & Kamboja & 109 & 97 & 85 & 85 \\
\hline
\end{tabular}

Index peringkat Indonesia di tahun 2015 naik signifikan dibandingkan 2012, namun tetap masih dibawah Singapura, Malaysia dan Thailand karena telah dibuka pelayanan investasi disatu pintu yang diserahkan ke BKPM sebagai leading sector pertama diharapkan juga bisa mempercepat waktu proses perizinan. Memang negara kita selama lima tahun dari 2012 telah terjadi kemajuan, terutama dalam kurun waktu lima tahun dari 2012 telah terjadi perubahan pelayanan yang lebih cepat tapi kemajuan ini masih kalah dibandingkan dengan negara lain utamanya dengan Singapura, Malaysia dan Tailand.

Menurut Direktur Eksekutif Instutute for Development of Economic and Finance (INDEF), buruknya pelayanan kita masih pada berbelit belitnya proses

${ }^{6}$ Makhfudz, Hukum Adminstrasi Negara, h.65. 
yang harus melalui tahapan prosedur yang panjang konon sampai melalui 19 kursi mulai dari pusat sampai daerah. Selain itu juga masih ada perbedaan kepentingan antara pusat dan daerah.

Setelah melihat deretan rangking negara-negara setara tersebut dimana Indonesia masih tertinggal, maka Presiden segera merubah proses perizinan dengan BKPM sebagai leading sektor utama untuk membuka pelayanan terpadu dengan maksud melakukan penyederhanaan prosedur dengan bentuk Pos Pelayanan Terpadu (PTSP) dengan mempersingkat secara bertahap mulai dari 90 hari berubah menjadi 33 hari di tahun 2010, kini diharapkan bisa menjadi 21 hari. Namun demikian masih juga ditemui kendala yaitu masih banyaknya pengutan liar. Presiden dalam menghadapi kondisi demikian kemudian mengambil sikap tegas, dengan segera membentuk Satuan Tugas Sapu Bersih Pungutan Liar dengan ditetapkannya Peraturan Presiden Nomor 87 Tahun 2016 tentang Satuan Tugas Sapu Bersih Pungutan Liar yang kala itu dibarengi dengan ditangkapnya petugas pengurusan surat-surat kendaraan di Dinas Perhubungan yang sedang melakukan pengutan liar dan menyusul di kepolisian. Namun menurut penulis kini gerakan sapu bersih itu terlihat mati suri tak ada suaranya lagi.

Kalau dilihat dari institusi yang menangani kemungkinan terjadi kendala/hambatan di kepolisian. Berbeda dengan KPK yang terus sigap tangkapi pelaku yang melakukan pungli atau suap yang menghambat kemajuan investasi, sebagaimana laporan pejabat yang berstatus tersangka korupsi. Komponen Negara sebagai alat perlengkapan negara seyogyanya mendukung langkah negara dalam hal ini eksekutif yang terus berusaha membersihkan hambatan laju investor. Sehingga layaknya DPR membantu langkah eksekutif dengan mendukung KPK dalam usahanya memberantas korupsi dengan satu-satunya alat atau sarana Operasi OTT dan penyandapan seperti pada lembaga sejenis KPK di Singapura dan Korea. Bukannya DPR malahan menghambat KPK dengan mengusulkan pembekuan KPK.

Daftar pejabat Berstatus Tersangka Korupsi dari Tahun 2011

\begin{tabular}{|l|l|l|l|l|}
\hline & \multirow{2}{*}{ Nama Jabatan } & \multicolumn{3}{|c|}{ Tingkat jabatan } \\
\cline { 3 - 5 } & & Eselon I & Eselon II & Eselon III \\
\hline 1 & Kemendagri & 1 & 1 & 3 \\
\hline 2 & Kemendes (PDT) & 1 & 1 & 3 \\
\hline 3 & Kemenhub & 1 & 1 & 3 \\
\hline 4 & KemenAgama & 1 & 1 & 3 \\
\hline 5 & Kemenkeu & 1 & 1 & 3 \\
\hline 6 & Anggota DPR & 99 & - & - \\
\hline 7 & Pengadilan & 4 hakim & & 3 panitera \\
\hline 8 & Bupati & 80 & & \\
\hline 9 & Sekda & & 24 & \\
\hline
\end{tabular}




\begin{tabular}{|l|l|l|l|l|}
\hline 10 & Gubernur & 3 & - & \\
\hline 11 & Kemenpora & 1 & 1 & \\
\hline 12 & Rektor & 3 & - & \\
\hline
\end{tabular}

Hasil pengamatan penulis melalui perkembangan di media

Angka-angka tersebut diatas menunjukan kerja KPK yang makin efektif dan dipengaruhi juga akuntabilitas publik yang meningkat dan juga pencegahan korupsi yang makin efektif. Peran KPK yang makin aktif, walau di tengahtengah perlawanan oleh DPR agar KPK terhambat dalam bongkar mega korupsi $\mathrm{E}=\mathrm{KTP}$.

Dari fenomena tersebut, penulis dalam renungannya menemukan hal-hal apa yang menjadi faktor penyebab dengan sebuah pertanyaan: apa sebenarnya yang menyebabkan munculnya fenomena yang memprihatinkan tersebut diatas? Dari hasil perenungan, penulis menganalisa ada beberapa kemungkinan yang ada benang merahnya adalah kurangnya disiplin berbangsa dan menurunnya nilai penjagaan terhadap kehormatan diri sebagai bangsa yang ditunjukkan dalam perilaku keseharian, terutama kurangnya sikap pemimpin-pemimpin bangsa yang dapat diteladani (role modeling).

Perlu dipahami peran pemimpin negara bukanlah semata-mata pemimpin tertinggi negara saja, tetapi juga pemimpin pada jajaran di bawahnya, mulai Menteri, Gubernur, Bupati/Walikota sampai Lurah. Kerja keras pemimpin akan sia-sia apabila jajaran di bawahnya tidak menampilkan performa sebagai hasil perilaku luhur yang sama. Dengan demikian tantangan ke depan kepemimpinan negara bangsa di antaranya adalah sampai berapa jauh amanat Pasal 33 UUD 1945 dan sila ke 5 Pancasila dapat terwujud, sehingga Indonesia semakin meningkat daya saingnya dalam percaturan negara-negara di dunia, khususnya di era globalisasi.

Pemimpin bangsa sebagai pemimpin tertinggi harus memiliki tatapan mata jauh ke depan, memikirkan masa depan bangsa agar bangsa ini tidak hancur tertelan lajunya zaman. Sebagaimana pada sejarah yang lalu, banyak bangsa yang hancur dan hilang musnah. Maka pemimpin harus memikirkan sebuah kelangsungan bangsa dan kelanggengan bangsa dengan sebuah ide membangun karakter bangsa, seperti gagasan pemimpin bangsa sekaligus sebagai pendiri bangsa dan negara (the faunding father) dengan pernyataan yang dikenal nation and caracter building. Namun ide besar itu sulit diwujudkan, karena tidak ada prinsip yang harus dipedomani. Hampir disetiap negara memiliki gagasan itu. Penulis bisa sebut di Malaysia yang disebut MSC (Multimedia Super Corridor) yaitu sebuah impian besar Malaysia untuk menjadi negara maju dalam bidang teknologi informasi. ${ }^{7}$ Dalam bidang pendidikan, Malaysia telah

${ }^{7}$ Suparlan, Med, Pendidikan Karakter, (Yogyakarta: Penerbit Hidayat, 2012), h.145. 
menjabarkan gagasan besar ini dengan apa yang disebut Smart School atau Sekolah Bestari.

Untuk membangun rasa persatuan dan kesatuan antar etnis, Malaysia telah mengembangkan model Sekolah Berasrama Penuh (SBP). Namun yang menjadi pertanyaan, di negeri kita sudah menerapkannya untuk menciptakan calon pemimpin daerah yaitu STPDN, sekolah calon Camat. Walaupun sampai ini masih terus dilanda noda kekerasan yang ditandainya dengan banyaknya peserta didik menjadi korban yang gugur akibat kekerasan yang terjadi hampir tiap tahun, dimulai dari tahun 2000.

Penulis berpendapat mungkin ada problem dalam pelaksanaan sistemnya. Namun harus tetap optimis, masih banyak contoh dalam sistem sekolah berasrama yang belum menghadapi kekerasan yaitu dipelaksanaan pondok-pondok pesantren, belum terdengar terjadi kekerasan, mungkin perlu mencontoh dan menerapkannya.

Menurut ahli pendidikan adalah salah satu model pendidikan karakter yang harus menjadi perhatian para pengelola dan pelaksana pendidikan yaitu model holistic terintegrasi ke dalam semua pelajaran dan semua kegiatan sekolah dengan melalui proses pembiasaan dan pembudayaan di sekolah. Atau yang dikenal dengan pendidikan karakter, selain harus menjadi budaya sekolah atau school culture. ${ }^{8}$

Dengan model ini, keberhasilan sekolah tidak hanya di pandang sebelah mata hanya dari satu aspek keberhasilan akademik saja, tetapi juga dari karakter yang mampu membentuk siswa menjadi pribadi yang memiliki kecerdasan emosional dan sosialnya. Model pendidikan karakter menurut konsep LSD (Life Skill Development) yang diterapkan melalui langkah-langkah sebagai berikut yaitu dengan menerapkan sepuluh (10) pilar karakter antara lain: a). Tanggung jawab, b). Disiplin, c). Percaya diri, d). Mandiri, e). Kerjasama, f). Jujur, g). Peduli sopan, h). Hormat dan, i). Sabar.

Kemudian dilakukan evaluasi terus dalam penerapan pendidikan karakter secara berkala dilakukan secara universal, lalu dilihat dampaknya terhadap hasil pendidikannya apakah telah memberikan pondasi yang kuat bagi kompetensi lulusan yang diharapkan. Misalnya pendidikan kejujuran yang diberikan ke peserta didik telah mampu membentuk perilaku jujur setelah menamatkan pendidikannya. Dampak inilah dari suatu proses pendidikan yang dapat diperoleh, cara berpikir kritis, berpikir rasional, bahkan juga pendidikan karakter dengan "Core Universal Ethical Value" yang diberikan tidak akan dapat secara instan kita lihat hasilnya. Melalui proses yang panjang setelah beberapa lama nanti bisa terlihat ada hubungan korelatif yang signifikan antara pelaksanaan pendidikan karakter dengan hasil belajar bila telah terlihat

8 Suparlan, Med, Pendidikan Karakter, h.139. 
meningkat pilar karakter, misalnya telah tercipta "semangat kerja keras", bila sudah maka pendidikan karakter dapat menjadi fundamen dasar yang kuat untuk meningkatkan daya saing di masa depan. Sehingga bisa diharapkan masa depan bila kelak sudah mengabdi pada negara menjadi pengabdi yang memiliki semangat kerja keras dan jujur.

Setelah beberapa dekade berlangsungnya proses pendidikan karakter, diharapkan telah menghasilkan generasi penerus yang baik, artinya berkarakter baik, bermoral luhur, sehingga baru kita lakukan pencarian pemimpin yang memiliki kepemimpinan luhur mendekati paripurna. Dalam membahas kepemimpinan ini, penulis mensitir dari pendapat para ahli antara lain memiliki unsur:

Pertama; Sikap Moral yang Luhur. Sebagai pemimpin sudah seharusnya mempunyai sikap yang berlandaskan kepada standar moral yang tinggi dengan kata lain seorang pemimpin diperlukan sikap moral yang meliputi pembentukan karakter yang berbudi luhur (caracter building). Selain itu juga seorang pemimpin harus mampu menguasai kemampuan yang tinggi untuk mewujudkan visinya yang dilandasi oleh nilai-nilai luhur perilaku dan keberanian untuk mengambil keputusan. Kemampuan tersebut harus didukung oleh kompetensi yang tinggi baik menyangkut pengetahuan (knowledge), keterampilan (skill) dan pematangan psikologis. Sebagaimana penulis menstir pendapat M Faisal Tamin (Mantan Menpan $)^{9}$ yang mengutip pendapat Keith Davis yang merumuskan unsur-unsur: 1). Human Perfomance= Ability (kemampuan)+ Motivation, 2). Motivation= Attitude (sikap)+ situation(situasi), 3). Ability= Knowloge (kemampuan Potensi) + skill.

Uraian secara psikologis, kemampuan (ability) kepemimpinan terdiri dari kemampuan potensi (IQ) dan kemampuan reality (knowloge + skill) artinya pegawai yang memiliki IQ yang tinggi dengan pendidikan yang memadai untuk jabatan dan terampil dalam mengerjakan pekerjaan sehari-hari, maka ia lebih mudah mencapai prestasi kerja yang diharapkan. Motivasi terbentuk dari sikap (attitude) seseorang dalam menghadapi situasi (situation), kerja motivasi merupakan kondisi yang menggerakan diri secara terarah untuk mencapai tujuan organisasi. Sikap mental merupakan kondisi mental yang mendorong untuk berusaha mencapai prestasi kerja secara maksimal. Faktor integritas juga ikut mendukungnya sebagai seorang pemimpin di segala tingkatan, karena orang yang memiliki integritas biasanya memiliki sifat yang jujur, tangguh dan berkualitas bisa menjadi pemimpin bagi dirinya, mengenal jati dirinya, sehingga sadar menjaga kehormatan diri dari perilaku yang tidak terpuji.

Dalam melengkapi kepemimpinan ini, penulis juga menstir pendapat Kouzer dan Posner dalam bukunya "The Leadership Cholege" yang mendefinisikan kepemimpinan adalah sebagai seni memobilisasi orang lain supaya ingin

\footnotetext{
${ }^{9}$ Bahan seminar Nasional ke 13 STIPAN 2017, h.8.
} 
berjuang mengejar aspirasi bersama. ${ }^{10}$ Kata ingin menurut Ermaya Suradinata kata 'ingin' dalam definisi ini menjadi penting, sebab tanpa kata 'ingin', maka kepemimpinan akan berubah banyak sekali. Selain itu tanpa kata 'ingin', maka kepemimpinan akan bermakna kurang melibatkan orang lain. Demikian juga pendapar Ronald Heifetz dan Laure berpendapat, kepemimpinan masa depan adalah seorang pemimpin yang adaptif terhadap tantangan, peraturan yang menekan, memperhatikan pemeliharaan disiplin, memberikan kembali berbagai keberhasilan organisasi kepada karyawan dan menjaga kepemimpinannya, sehingga menurut Ermaya, kunci sukses pemimpin adalah bila pemimpin itu mampu menjaga kepercayaan para pemangku kepentingan dan menjunjung tinggi norma dan nilai etika kehidupan. Oleh karena itu, seluruh individu dalam organisasi, baik pemimpin maupun karyawan secara mandiri maupun bersamasama harus mentaati etika dan mematuhi setiap peraturan organisasi maupun perundang-undangan yang berlaku. Karena etika dan tata laku kepemimpinan merupakan salah satu wujud komitmen melaksanakan praktek-praktek good Corporate Governance, untuk mencapai visi dan misi organisasi. Visi dan misi organisasi harus memiliki tata nilai unggulan yang di dalamnya ada unsur-unsur sebagai berikut:

a. Integritas, bersikap jujur, adil, dan terbuka serta bertanggung jawab.

b. Belajar terus menerus, selalu meningkatkan kompetensi sesuai bidangnya masing-masing.

c. Terpanggil, bekerja dengan segenap kehati-hatian, tulus dan iklas dan rasa syukur.

d. Peduli sama semua, menjaga keharmonisan hubungan menjaga tata dan perbuatan.

e. Berpikir kreatif menerima dan terbuka terhadap ide-ide baru.

f. Beranggung jawab, menuntaskan masalah bukan sekedar mencari penyebabnya atau bukan menutupinya.

Kemudian Ermaya mengemukakan hasil pemikirannya tentang kepemimpinan yang dikenal dengan nama "Modal Analisis "ASOCA" yaitu bagaimana menerapkan kepemimpinan sebagai strategi dalam membangun karakter bangsa Indonesia. Ini sebuah konsep pengembangan dengan memperhatikan khusus pada aspek ability yaitu kemampuan aspek Streght yaitu mengandalkan kekuatan. Aspek apportunity yaitu kesempatan dan aspek culture yaitu budaya yang sangat menentukan adanya Agility yaitu kecerdasan.

Dari pendapat ahli tentang kepemimpinan yang baik, semua mengemukakan pentingnya moralitas pada jiwa pemimpin, demikian juga Prayudi Atmosudirjo berpendapat bahwa untuk menjadi pemimpin harus

${ }^{10}$ Bahan Seminar Nasional ke 13 STIPAN 2017 
memiliki syarat-syarat untuk bisa menyelenggarakan pemerintahan. Diantaranya adalah: ${ }^{11}$

1. Efektitifitas, kegiatan harus mengenai sasaran artinya kesejahteraan seluruh rakyat bukan sekelompok saja tentunya.

2. Legitimitas; kegiatan administrasi negara jangan sampai menimbulkan kehebohan karena tidak dapat diterima oleh masyarakat setempat atau lingkungan yang bersangkutan.

3. Yuridiksitas; syarat-syarat yang menyatakan bahwa perbuatan para pejabat adminstrasi negara tidak boleh melanggar dalam arti luas.

4. Legalitas; syarat yang menyatakan bahwa perbuatan atau keputusan adminstrasi negara tidak boleh dilakukan tanpa dasar undang-undang. Bila sesuatu dijalankan dengan dalih keadaan darurat, keadaan itu wajib dibuktikan kemudian. Jika tidak terbukti, maka perbuatan itu dapat digugat di pengadilan

5. Moralitas; salah satu syarat yang paling diperhatikan dalam masyarakat, moral dan etika ataupun kedinasan wajib dijunjung tinggi.

6. Efisiensi, wajib dikejar seopimal mungkin, kehematan biaya dan produktifitas wajib diusahakan setinggi-tingginya.

Namun perkembangan yang terjadi di lapangan yang terjadi di negeri tercinta, dilihat dari sikap moral pemimpin nampak aneh seperti penulis lihat. Contoh pemimpin kita yang suka menyanjung hasil kerjanya sendiri, yang menurut falsafah leluhur tak layak. Sehingga kini dimanifestasikan melalui keinginan politik untuk bisa mempertahankan kekuasaannya yang kedua kalinya.

Manifestasinya melalui sebuah kebijakan berupa peraturan perundang undangan baru yang mengatur proses demokrasi agar terlihat praktek demokrasinya secara legal dan yuridis konstitusional, yaitu melalui pembentukan undang-undang yang mengatur calon presiden dari partai politik dengan nama "presidential threshold" yang berisi syarat partai untuk bisa mengajukan calon presiden, agar tercipta capres calon tunggal yang menurut pikiran politisi partai penguasa bisa berkuasa kembali dengan mudah. Kemudian nanti pelaksanaan pemilu capresnya calon tunggal, caranya agar lebih demokratis, calon Presiden nantinya harus melawan kotak suara kosong dengan ketentuan bila ternyata pemilih lebih banyak mengisi kotak suara kosong, maka capres tadi tak boleh mencalonkan lagi.

Dari analisa permasalahan ini penulis mencuplik pendapat dari Jimly Asshidiqie dalam laporannya dari apa yang terjadi di Rusia yang dicap sebagai

${ }^{11}$ M. Makhfudz, Hukum Adminstrasi Negara, h.12. 
negara yang tidak menganut demokrasi ternyata lebih demokratis ketimbang kita. Menurut beliau bahwa yang terjadi Rusia mempersilahkan pihak independen non partai untuk menyuarakan kemauan dan pendapatnya. Jadi menurut penulis jauh berbeda demokrasi kita yang terlihat demokratis yang dibuat-buat menurut kemauan kelompok penguasa dengan koalisinya yang permanen dengan kekuatan memaksa.

Ageng Wahyudi dalam pendapatnya menyatakan etika termasuk etika birokrasi mempunyai fungsi yaitu pertama; sebagai pedoman, acuan, referensi bagi adminstrasi negara birokrasi publik dalam menjalankan tugas dan kewenangannya agar tindakan dalam organisasi dinilai baik, terpuji dan tidak tercela. Kedua; etika birokrasi sebagai standar penilaian mengenai sifat, perilaku dan tindakan birokrasi publik yang dinilai baik, tidak tercela dan terpuji. ${ }^{12}$ Demikian pula Anderson yang menambahkan suatu poin baru yaitu: standar yang digunakan sebagai dasar keputusan tersebut sedapat mungkin merefleksikan nilai-nilai dasar dari masyarakat yang dilayani.

Setiap birokrasi pelayanan publik wajib memiliki sikap mental dan prilaku yang mencerminkan keunggulan watak, keluhuran budi dan asas etis. Seorang birokrat wajib mengembangkan diri, sehingga sungguh-sungguh memahami, menghayati dan menerapkan berbagai asas yang bersumber pada kebijakan-kebijakan moral, khususnya keadilan dalam tindakan jabatannya secara nilai-nilai moral terlihat dari enam nilai besar atau yang dikenal dengan six great ideas 5 (lima) tahun yaitu nilai kebenaran (truth), kebaikan (goodness), keindahan (beauty), kebebasan (liberty), kesamaan (equality), dan keadilan (justice).

Dalam kehidupan bermasyarakat seseorang dinilai dari tutur katanya, sikap dan perilakunya sejalan dengan nilai-dengan nilai tersebut atau tidak begitupula dalam pemberian pelayanan publik, tuturkata, sikap dan perilaku para pemberi pelayanan seringkali dijadikan objek penilaian dimana nilai-nilai besar tersebut dijadikan ukurannya. Disamping nilai-nilai dasar tersebut mungkin ada juga nilai-nilai lain yang dianggap penting untuk mensukseskan pemberian pelayanan yang dari waktu ke waktu terus dinilai, dikembangkan dipromosikan. Dalam dunia pelayanan publik etika diartikan sebagai filsafat moral atau nilai disebut dengan "professional" Standart" (kode etik) atau "Right Rules of conduct" (aturan perilaku yang benar) yang seharusnya dipatuhi oleh pemberi pelayanan publik. Sebuah kode etik merumuskan berbagai tindakan apa kelakuan dan sikap bagaimana yang wajib dijalankan atau dihindari oleh para pemberi pelayanan.

Aplikasi etika dan moral dalam praktek dapat dilihat dari kode etik yang dimiliki oleh birokrasi publik. Kode etik ini terlihat tidak tertulis khususnya, tapi sebetulnya ada setiap ajaran agama, seperti Islam ada di Alquran dan hadis, misalnya ada ajaran Nabi Mumammad yang memerintahkan agama dalam

${ }^{12}$ Jurnal Pemerintahan, Vol 11 Nomor 2, Jakarta, Juli 2016 ISSN 1693-072X h.40. 
setiap melayani harus selalu dengan senyum. Namun masyarakat belum bisa menghayati apalagi mengamalkan dalam lingkungan di birokrasi tidak ada pemimpin memberi contoh, kode etik yang dimengerti masyarakat di Indonesia hanya berlaku bagi kalangan khususnya seperti ada di Advokat dan dokter. Kode etik tidak hanya sekedar bacaan, tetapi harus diimplementasikan dalam melaksanakan tugasnya dinilai tingkat implementasi melalui mekanisme monitoring, kemudian dievaluasi dan diupayakan perbaikan melalui komitmen.

Komitmen terhadap perbaikan etika ini perlu ditunjukkan agar masyarakat semakin yakin, bahwa birokrasi publik sungguh sungguh akuntabel dalam melaksanakan kegiatan pelayanan publiknya. Seseorang aparatur yang telah mengetahui kode etik yang dari agama hilang setelah menduduki jabatan. Seolah jabatan itu bisa menutupi kejelekan budinya, akhirnya terjerumuslah mereka, lupa kewajiban melakukan pelayanan.

Dari fenomena kepemimpinan yang sering penulis lihat, pemimpin tak lagi memegang prinsip sebagai seorang pemimpin yang harus bisa menjadi tauladan bagi rakyat, karena sudah terjadi di lapangan etika telah dilanggarnya yaitu dengan sikap yang suka menyanjung dirinya, seperti terlihat jelas dalam ungkapan di berita bahwa akan direncanakan pembangunan tranportasi ramah lingkungan berupa MRT, dengan melihat kecanggihan dan keistimewaanya ketimbang negara lain. Padahal negeri kita tergolong negara di lingkup ASEAN yang telah ketinggalan di banding negara ASEAN lainnya. Kemudian juga dengan akal yang sebetulnya sangat licik yang menurut leluhur tak patut dilakukan yaitu dengan membuat aturan yang menggiring agar partai politik selain koalisinya tak bisa lagi mengajukan capres sebagai lawannya. Setiap tindakan pegawai ASN yang juga sebagai aparatur negara dalam kondisi era reformasi terus menjadi sorotan masyarakat, masih ada dan harus dilayani bukan melayani pelayanan yang mudah dibuat sulit dan berbelit lama dan mahal, melenceng dari kewajiban yang sudah diatur, serta banyak sekali melakukan mal adminstrasi seperti tercermin yang dilakukan oleh pemimpin daerahnya baik Gubernur, Bupati/Walikota yang berhasil ditangkap pada operasi OTT KPK sampai berjumlah 80 (Bupati/walikota). Mereka semua telah menghidupkan kembali budaya KKN (kolusi, Korupsi dan Nepotisme), misal telah menghidupkan kembali aksi jual beli jabatan di lingkungan, terlihat sekali peran partai dalam membangun kadernya untuk menjadi pemimpin telah gagal, terbukti ada partai yang mayoritas kadernya jadi pemimpin daerah telah melahirkan kolusi dengan melakukan jual beli jabatan dan sebagainya. Sehingga terjadi hal yang tidak indah dipandang mata, karena telah melanggar nilai keindahan (beauty) dimana pemimpinnya tertangkap OTT KPK sedang bawahannya menyambut dengan eforia. Jadi di era reformasi telah terjadi pelanggaran komitmen janji reformasi sebagaimana ditetapkan dalam UU No.28 Tahun 1999 tentang Penyelenggaraan Negara yang bersih dan bebas korupsi, kolusi dan Nepotisme (lembaran Negara RI No.75 tahun 1999, sedang rezim ini 
sedang menunjukkan kegagalannya melawan KPK yang telah ditunjuk keberaniannya memenangkan kader partai. Dengan Pansus Angket KPK sedang berusaha melawan KPK karena dianggap bermain politik, sehingga terus berusaha membekukan KPK agar berhenti melakukan OTT kader partai. Menurut penulis kini rezim ini sedang menunjukkan barisan koruptor yang masih kuat melawan KPK, terbukti dengan gerakan membekukan KPK dengan melakukan kerjasama DPR.

DPR, kejagung dan kepolisian telah mengadili KPK seolah-olah KPK telah bersalah. Mereka telah mengundang para koruptor yang telah menjalani hukuman oleh KPK atau melalui peradilan Tipikor dipandang istimewa ke DPR untuk mengadili KPK seolah-olah melanggar konstitusi. Ketiga lembaga tindakan menyerang KPK diimbangi dengan sikap Presiden yang diam seolah olah merestui, hanya terkadang mengeluarkan suara dari istana, mengharapkan KPK diperkuat tidak sesuai dengan kondisi, senyatanya dimana KPK sedang dijepit, diserang dilucuti sedang mereka seolah-olah tidak mengetahuinya. Penulis hanya mengapa diam. Tak ada daya untuk mengkritisi pintu-pintu yang telah ditutup oleh rezim yang terbukti banyak menangkapi rakyat yang kritis.

Penulis menyetir pendapat dari Jeffry Winster, menurut penelitian bahwa di negeri tercinta Indonesia ini telah terbentuk yang disebut oligarchi democratie, yang merubah sikap DPR yang prodemokrasi menjadi non demokrasi. Sehingga membuat undang-undang sesuai pesanan penguasa yang ingin berkuasa lebih dari satu periode. Kini DPR telah merubahnya dengan wajah yang tak demokratis menjadi lembaga yang super adi daya, tak bisa dikoreksi tercermin telah merumuskan Rancangan undang-undang MD3 yang tidak disahkan oleh Presiden. UU MD3 yang isinya melarang rakyat mengkritik anggota DPR terhormat, dan telah membungkam Presiden dan MK untuk mengabulkan uji materi UU KPK yang sebetulnya sudah pernah memutus sebelumnya, dan kini memaksanya untuk membuat keputusan yang kontraproduktif. Fenomena ini menurut penulis bisa menjadi pembelajaran politik bagi masyarakat memilih untuk membekalinya menghadapi proses demokrasi baik itu Pilkada maupun Pemilu agar rakyat tidak menjadi objek komoditi politik partai, tetapi bisa membuatnya cerdas dan peka untuk mengambil keputusan dalam melakukan hak pilihnya tidak lagi didikte oleh partai politik. Pemilih bisa peka melakukan hak pilihnya dengan melihat informasi kader partai mana dari pemimpin daerah yang tertangkap OTT KPK dan kini bisa melihat pergerakan emigrasi pendukung fanatisme yang sudah mulai berpindah seperti di daerah banten, Medan Yogya dan Bandung serta Jakarta yabg tadinya sebagai pusat partai tertentu kini pindah dukungan ke partai lain.

Pendukung partai melakukan rotasi pindah dukungan adalah hal yang wajar, karena mereka telah cerdas membaca fenomena untuk menghindari perilaku pemimpin yang anti koperatif dan terbukti telah menghidupkan 
perilaku jelek yang telah menyimpang komitmen reformasi dengan menuntut para aparatur pemerintah untuk mengembangkan akuntabilitas moral pada diri mereka. Namun sayangnya, tanggung jawab moral dan tangung jawab professional belum hidup di hati nurani apara aparatur ASN, sehingga untuk menilai baik buruknya pelayanan tergantung pada penerapan nilai-nilai sebagai berikut:

Pertama; efisiensi para birokrat tidak boros dalam melakukan tugas-tugas pelayanan pada masyarakat. Artinya para birokrat secara hati-hati agar memberikan hasil yang sebesar-besarnya kepada publik. Dengan nilai efesiensi lebih mengarahkan kepada penggunaan sumber yang dimiliki secara cepat dan tepat tidak boros dan dapat dipertanggunjawabkan kepada publik. Jadi dapat disebut baik (etis), jika birokrat dalam melakukan tugasnya sesuai dengan kewenangan.

Kedua; efektifitas yaitu birokrat dalam melaksanakan tugas pelayanan publik harus baik (etis), apabila menentukan target atau tujuan yang telah ditentukan sebelumnya yang belum tercapai. Ketiga; kualitas pelayanan yang diberikan oleh para birokrat kepada publik harus memberikan kepuasan kepada yang dilayani. Keempat, responsifitas yaitu berkaitan dengan tanggung jawab birokrat atau merespon kebutuhan publik yang sangat mendesak. Birokrasi tidak menjalankan tugasnya dinilai baik jika responsible dan memiliki profesional atau kompetensi yang sangat tinggi. Kelima; akuntabilitas artinya dapat dipertanggungjawabkan dalam melaksanakan tugas dan kewenangan dalam pelayanan publik. Birokrat yang baik adalah birokrat yang akuntabel dalam melaksanakan tugas dan kewenangannya.

Kode etik profesi adalah daftar kewajiban yang harus ditaati dan dibuat oleh profesi tertentu serta mengikat semua anggota dan merupakan petunjuk atau pedoman yang menujukan arah moral bagi suatu profesi sekaligus menjamin kualitas mutu moral di mata msyarakat. Biasanya itu berwujud norma yang tidak tertulis, namun diakui hidup di lingkungan serta dipatuhi oleh semua lingkungan anggota masyarakat, wujudnya bisa diajarkan agama yang ada di lingkungannya, selain adapula diwujudkan dalam aturan tertulis dengan satu aksi yang pengenalannya bisa dipaksakan seperti kode etik advokat, kode etik kedokteran. Kini juga diperlakukan bagi ASN dengan maksud agar ASN bisa menjaga martabat kehormatan pegawai.

ASN diatur dalam UU RI No.5 Tahun 2014 tentang ASN Pasal 5 ayat 2 berbunyi: a). Melakukan tugasnya dengan jujur, bertanggungjawab dan berintegrasi yang tinggi; b). Melaksanakn tugasnya dengan cepat dan disiplin; c). Melayani dengan sikap hormat, sopan dan tanpa paksaan; d). Melaksanakan tugasnya sesuai dengan perintah atasan atau pejabat yang berwenang sejauh tidak bertentangan dengan ketentuan perundang-undangan dan etika pemerintahan; e). Melaksanakan ketentuan peraturan perundang-undangan 
etika pemerintahan; f). Melaksanakan ketentuan peraturan perundang-undangan menegenai disiplin pegawai ASN.

\section{Dagelan Pelaksaan Pemilihan Calon Pemimpin Ala Reformis}

Kini memilih pemimpin menjadi hal yang sulit karena kini pemimpin bisa datang melalui pemilihan politis. Sedangkan pemilihan partai tentu caranya berbeda menurut partainya dengan perkembangan yang menguntungkan partai. Jadi bak membeli kucing dalam karung. Dalam arti baku tentu yang diidolakan rakyat, walau dengan segudang prestasi. Kata partai seperti dirakyatnya walau dengan segudang prestasi partai seperti dicontohkan figur Bupati tegal, katanya memiliki segudang prestasi, tetapi dari bidang prestasi yang berbeda.

Akhirnya kenyataan prestasi tersebut tidak sesuai harapan semua rakyat. Ternyata Bupati dalam kerjanya telah menghidupkan sesuatu yang tidak diharapkan, karena membuat pelayanan menjadi berbelit belit demikian juga dirasakan tak bisa menjamin kariernya yang bisa dijadikan motivasi atas prestasi yang ditunjukkan oleh pegawainya, karena dibuat jual beli jabatan. Pegawai yang bisa meniti karier hanya bisa dicapai oleh mereka yang memiliki uang, karena harus membayar. Hal ini terjadi yang dilakukan oleh para Bupati di beberapa daerah, utamanya di Jawa Tengah, seperti Kebumen, Tegal, Ngajuk, Klaten, dan sebagainya. Untung KPK sigap berhasil menangkap, sehingga bisa diberhentikan praktek jual beli illegal tersebut.

Jadi perubahan yang harus dilakukan secara serempak berupa regenerasi pada partai guna membangun kader-kader, menciptakan pemimpin masa depan, seperti dilakukan oleh partai partai zaman dahulu (orde lama), seperti penulis kenal tokoh dahulu kala, Alisastri Amijoyo, Sutan Syahrir, M. Natsir, Rasid Baswedan (ayahnya Bapak Anis). Tokoh-tokoh tersebut telah bisa menunjukkan sikap dan perilaku yang jujur dan mulia. Penulis menilai beliau-beliau sebagai pemimpin yang telah mampu menguasai kemampuan yang tinggi untuk mewujudkan visinya yang dilandasi oleh nilai-nilai yang luhur perilaku dan keberaniannya mengambil keputusan. Demikian juga kemampuan yang didukung oleh kompetensi yang tinggi baik menyangkut pengetahuan (know ladge), keterampilan, skill, maupun kemantangan psikologisnya. Tidak seperti orientasi partai masa kini yang hanya bisa menunjukkan diri bila telah menjadi pengurus partai dan menjadi kaya mendadak, harta berlimpah tidak tahu harta dari mana sumbernya. Semua hal itu tidak terjadi bila para pemimpin memiliki sikap yang konsisten dalam bidang disiplin berperilaku yang dilandasi pada pedoman hal-hal yang sesuai dengan petunjuk sang pencipta, sehingga bisa memiliki mainset sebagai seorang pemimpin yang lebih mengarah kepada pemimpin yang amanah. Kewajiban bukan hak, dengan demikian ia akan memimpin kebersihan hati nurani, bukan menumpuk harta dan sebagainya. 
Sungguh aneh dan jauh dari kriteria kepemimpinan khas Indonesia yang unggul diwacanakan antara lain: a). Beriman dan bertaqwa yang terpencar dalam sikap moral, akhlak yang mulia dan karakter yang terpuji, sehingga menjadi jati diri; b). Memiliki kepemimpinan yang telah teruji, termasuk didalamnya harus memiliki visi yang jelas; c). Memiliki wawasan sebagai faktor panduan harmonis dari kecerdasan intelektual dan kecerdasan emosional serta kecerdasan spiritual; d). Memiliki keluarga yang sakinah, mawadah dan wa Rahmah; e). Memiliki kesehatan jasmani yang memadai dengan mendapatkan dukungan dan kepercayaan dari rakyat. Sungguh prihatin antara wacana yang diharapkan jauh dari hasil yang bisa dilihat dan dirasakan oleh rakyat.

Penulis berpendapat setelah melakukan penelitian di lapangan dan pengamatan, sikap partai kerap kali berubah, bahkan cendrung lebih buruk, karena calon yang digadang-gadang bukan berasal dari kalangan kadernya. Tetapi berdasarkan atas hasil transaksional. Sang calon disuruh membeli partai yang menjamin dukungan dengan uang yang sangat besar, konon sampai ratusan milyar.' Sehingga yang kini menjadi tokoh sentral partai besar bersifat menunggu sampai melihat dukungan rakyat di lapangan, baru kemudian mendekati guna melakukan nego bak dagang sapi. Jadi calon pemimpin bukan tokoh yang digadang-gadangkan, karena tidak berasal dari kader yang telah dibangun partainya. Penulis merasa sangat perihatin akan masa depan bangsa yang makin jauh dari harapan. Kalau bisa ditemui pemimpin yang sukses dengan daerahnya makin baik makmur itu hanyalah faktor kebetulan saja, bukan hasil pengkaderan partai. Wacana ideal diatur hanya sekedar bacaan saja yang tidak ada gunanya bagi bangsa.

\section{Kesimpulan}

Dari pembahasan permasalahan bangsa diatas yang diceritakan panjang lebar mulai dari gejolak negara bangsa yang terjadi di seluruh jagad raya ini dalam menghadapi globalisasi, demikian juga permasalahan negara bangsa yang menghadapi krisis kepemimpinan untuk meningkatkan daya saing bangsa maka dapat disimpulkan:

Pertama; Penulis dalam menulis naskah ini banyak membahas perubahan lembaga pelaksana demokrasi yaitu DPR yang makin dominan dan berkembang menuju lembaga superpower.

Kedua; Penulis juga telah menggambarkan kondisi negara dalam memilih calon yang makin jauh dari nilai-nilai demokrasi yang sehat, karena dengan adanya usaha menutup celah partai politik untuk mengusulkan calon pemimpinnya dengan syarat yang berat dikenal dengan nama "presidensial threshold" sehingga memaksakan adanya calon tunggal dimana calon pemimpin disandingkan dengan kotak suara kosong. Konon akan didemontrasikan melalui 
pelaksanaan, baik di Pemilukada di sepuluh kota dan pemilu nasional dimana calon pemimpin disandingkan dengan kotak kosong. Pantaskah pelaksanaan demokrasi seperti itu?

Ketiga; Penulis juga dalam naskah ini telah membahas kondisi aparatur sipil negara, mulai dari kondisi penghayatan dan pengamalan terhadap nilai nilai etika dan kondisi penghayatan terhadap kode etik yang telah dirumuskan dalam sebuah aturan tertulis yaitu Undang-Undang Nomor 5 tahun 2004 tentang ASN terbaru yang mengatur kewajiban ASN nya sebagai kode etik yang dipaksakan.

Mari renungkan pelaksaan dagelan pemilu maupun pemilukada dimana calon pemimpin disandingkan dengan kotak kosong. Pertimbangkan dengan pertanyaan, elokkah pelaksaan pemilu di negara yang memiliki nilai-nilai luhur Pancasila dibandingkan dengan Rusia yang sering menjadi celaan bangsa kita.

\section{Daftar Pusaka}

Fernada MSO, Desi, Etika Organisasi Pemerintah, LANRI, 2006.

Pasulong, Harbani, Perilaku Birokrasi Dalam Pelayanan Publik, Penerbit Andi Jakarta, 2010.

Makhfudz, M., Hukum Adminstrasi Negara, Yogya: Graja Ilmu, 2013.

Suparlan, Pendidikan Karakter, Hikayat, 2012.

Sofiah, Perilaku Organisasi, Jakarta: Penerbit Andi, 2008.

Miftah, Toha, Deregulasi dan Debirokrasi Dalam Upaya Peningkatan Pelayanan Masyarakat, Pembangunan Adminstrasi di Indonesia, Jakarta: PT Pustaka, LPES, 1999.

Blaw, Peter M, and Marshall, Meyer, Birokrasi dalam Masyarakat Modern, Jakarta: Penerbit Prestasi Pustaka Raya, 2000.

Philipus, M Hadjon, Pengantar Hukum Adminstrasi Indonesia, tth.

bahan Seminar Prof Jimly Assidiqqi demokrasi di Rusia dan Jeffry Winter, Introduction to Indonesian Adminstrative Law, Yogyakarta: Gajah Mada University press, 2002.

Pasca Reformasi, Jakarta: Bhuana Ilmu Popular, 2009

Jurnal Hukum dan Pembangunan, Tahun ke 41 No.1 Januari 2011 ISSN 0215,9687

Jurnal Pemerintahan, vol 11 No.2 juli 2016 ISSN 1693072 X Buletin Swara ISSN 1425536 Edisi 10 tahun 2004

Undang-Undang No.28 Tahun 1999 tentang Penyelenggaraan Pemerintahan yang Bersih dari KKN 